\title{
Conservancy of forest shelter belts in Russia and the Rostov region as one of the factors of transition to a green economy
}

\author{
Maria Rodina ${ }^{1 *}$ \\ ${ }^{1}$ Don State Technical University, Gagarin sq., 1, Rostov-on-Don, 344000, Russia
}

\begin{abstract}
Today forestry in Russia is going through one of the most difficult periods in its history, which has resulted in decades of extensive wasteful land use. So, change of climate can bring desertification of some territories and various forms of degradation (desertification) cover about 60 percent of the land in the Rostov region, and the rest is potentially dangerous in this regard. The reasons are anthropogenic impact, drought, erosion, deflation. Despite the fact that in recent years Russia has been developing forestry legislation and has taken a course towards the development of sustainable growth and "green" one, the regions are taking measures aimed at protecting lands from degradation and preserving soil fertility, soil-destructive processes and desertification are increasing many times over. An inventory of forest resources in Russia was carried out in 2019 and it showed that the forest cover in Russia tends to decrease, and on the territory of the Rostov region, forest inventory was carried out in 2006 , only $40 \%$ of all forests were taken into account - about 240 thousand hectares of protective forest plantations, from of them 125.8 thousand hectares are shelter belts. It's imperative to enact urgent measures for reforestation and landscaping of territories and annually reconstruct forest belts and create new ones to improve environmental conditions in regions with low forest cover, otherwise in 10-15 years their mass natural death may occur.
\end{abstract}

\section{Introduction}

In our days the protection and restoration of forests, the improvement of legal regulation of the forestry sector is mega-important and mega-actual ecological problem in the Russian Federation. The lack of effective reforestation hinders the fulfillment of the scope of engagement by the Russian leader to ensure the balance of disposal (slashing and loss of forests from fires) and reproduction of forests by 2024 within the framework of the national project «Ecology» and the federal project «Conservation of Forests».

Governmental goals and strategic objectives emphasized in the edictions of the President of the Russian Federation, as well as the need by 2030 to significantly increase the contribution of the forestry complex to the country's economy led to the authorization of

* Corresponding author: Puta 1990@mail.ru 
new legal documents in the sphere of forest law relations in the Russian Federation until 2030, which noted that at the moment the potential contribution of the forestry sector to the Russian economy is significantly less than analogous indicators in other concurrent countries comparable with Russia.. Among the priority areas of this document are named: digitalization of the forest industry, development of reforestation mechanisms, forest conservation, protective custody and reproduction of forests, and others, and it is assumed that the state will finally be able to move to an intensive model of forestry based on the principles of sustainable forest management.

Despite significant adjustments to land and forestry legislative aspects, up until the discussion of the new Forest Code of the Russian Federation, in recent years, meaningfully updating the scope of use, protection and reproduction of forests, the legislator has not yet paid due attention to the protective forest belts of Russia. Moreover, the Chairman of the lower house of Russian parliament on Agriculture issues V.I. Kashin said that the forest belts remaining in the country today were pitiful remnants in his report back in 2018. The condition of such strips is not only unsatisfactory, but they are actually abandoned and have already turned into a breeding ground for various pests, a garbage dump and a powder keg. Thus, the issues of agroforestry and restoration of forest protection belts in Russia and the Rostov region during the transition of the state to a new era of sustainable growth and green development deserve special attention, which predetermines the relevance of the research topic.

\section{Materials / methods}

This foundation is based on the works of Russian scientists Kulik K.N., Koldanova V. Ya., Sergeeva M., Novikova E.M. and others, as well as foreign researchers - Dong-Xin Li, Taewon Kang, Taimoor Hassan Farooq, Awais Shakoor, Xiaohong Wu, Yong L and another ones. The methodological foundation of the research was described by the method of comparative jurisprudence, dialectics, as well as systemic and structural analysis.

\section{Results}

Russia is the richest country in terms of the number of forests and forest-protection reclamative belts, but today we can observe a howling situation, since the Russian forestry is going through one of the most difficult and troubled periods in its history. After decades of extensive forest use, mismanagement and lack of a sufficient legal basis, immediate action is required to restore the forestry sector from deep decline, since such negative processes have been taking place for an extremely long time, when the original forests were destroyed, including illegally, lands unsuitable for agriculture were plowed up and other economic activities were carried out. As a result, the fragile balance of nature was violated, the climate changed, wind and water erosion increased many times, streams, rivers, wells dried up and disappeared, the saturation of soils with mineral salts increased, that is, the anthropogenic impact on ecosystems and in the global one increased dramatically, and on a regional scale, which led to a decrease in their bioproductivity and self-healing ability, and soils, which play a critical role in world food production, have ceased to be healthy and productive and are gradually turning into desert territories, degrading and busting up.

The degradation of land resources in Russia is growing at an exponential rate, the main agricultural regions of Russia have plowed up agricultural land by $60-90 \%$, significantly exceeding the acceptable limits, as a result of which an ecological and economic catastrophe of the agricultural sector is possible in the very near future, since $65 \%$ are currently exposed to the destructive impact. arable land, $28 \%$ of hayfields and 
$50 \%$ of pastures, while, as you know, the disappearance of forests often led to disasters drought and famine of the first half of the XX century in the Volga region, loss of life, dust storms in southern Russia, which took away millions of hectares of fertile black earth soils of agricultural land. According to UNEP, almost a quarter of the dry hard of our planet is threatened with desertification (about 2 billion hectares, there is a tendency for an annual increase of 12 million hectares), which is the most important threat to biodiversity on the Earth. Desert advancing leads to the degradation of droughtafflicted, semi- drought-afflicted and dry sub-humid land because of different factors, including change of climate and human activities. Besides, it is hard to come by an accurate quantitative estimate of the consequences of increasing aridity, which requires urgent investment in more targeted research to further develop future instruments to counter the negative effects of climate change [1].

On June 17, 2020, on World Day to Combat Desertification and Drought, UN Secretary-General António Guterres and UN General Assembly President Tijani Muhammad-Bande pointed out that the health and well-being of the world's society depends on the health of the planet, which is now sick, because on today, $75 \%$ of soils have been degraded and every year the planet loses millions of hectares of fertile land, as a result of which the natural balance is disrupted, which leads to environmental, climatic, social and other disasters of a global scale [6]. Climate change leads to a constant threat to nature and humans and, therefore, requires adaptability and flexibility in forestry and domestic land use management [2].

In April 2021, the scientific director of the Hydrometeorological Center of Russia, Roman Vilfand, spoke about the tendencies of climate change in different regions of the Earth, pointing out, in particular, that aridity will increase, and the amount of precipitation will decrease in the southern regions of Russia.

The world community has long recognized desertification as an acute problem in many countries of the planet in economic, social and environmental terms [3, 4]. Russia ratified these documents - the UN Framework Convention on Climate Change and the Protocol to it back in the early 2000s, however, it was only in February 2021 that Russian Prime Minister Mikhail Mishustin set the task of creating a Center to Combat Desertification of Territories before the relevant state bodies.

In the economic context of complex and unstable processes, food and climate crises, the problem of providing the population with the necessary resources without causing damage to the environment is becoming increasingly acute. One of the basic postulates of green development of socio-economic systems is effective management of ecosystems and their preservation [5], since scientific and technological progress has significantly aggravated the deterioration of the ecological situation and increased socioeconomic tension in the countries of the world. Interesting is the experience of developing a green economy in Japan and South Korea, which have already achieved certain results in this area to reduce pressure on the natural world and make significant investments in environmental protection - the driving force behind economic growth and achieving sustainable development, including preserving the environment, including biodiversity. , forests and oceans [6], the introduction of the content of environmental protection and environmental ethics related to green growth in educational material [7], as well as in China, where the transition to a green economic model is a complex strategic task that requires a combination of two previously incompatible development vectors: maintaining dynamic economic growth and preserving the natural environment on a long-term basis [8-10]. It is noted that, based on the general ideology of the concept of sustainable development, enhancing economical state of the nation and increasing energy efficiency depends on the active position of the authorities at the federal and regional levels [11]. 
In 2013 the main directions in the field of environmental safety within a green economy were proclaimed, but today the formation of green law in Russia is hampered in the absence of special legislation [12].

The previous Strategy in the forestry advancement relations in Russia until 2030 (dated September 20,2018) pointed out problems that do not allow the forestry complex in the Russian Federation to develop properly, among others, these are low productivity of reforestation, protection and conservation of forests and forest belts, obsolete information about forest resources, as well as the fact that there are technical, scientific, educational and staffing and imperfection of the regulatory framework of the forestry law and related branches of law.

Viktoria Abramchenko, Deputy Prime Minister of the Russian Federation for Agriculture, Ecology and Real Estate Turnover, in her report in January 2021, notes that the new Forestry Strategy will solve a number of key problems and, above all, will help to "reverse" the situation with forest restoration, since the country has accumulated more than 35 million hectares, on which reforestation has not been carried out, and each year their number becomes another 450 thousand hectares more.

However, unfortunately, there is also a negative perception of these documents. Thus, the authors believe that the Strategy does not propose or discuss economic mechanisms to stimulate the transition to an intensive forest management model, does not suggest mechanisms for resolving problems associated with such a factor as environmental responsibility, the text of the strategy does not contain a single mention of the need to preserve massifs of intact forest areas (MLT) and the creation of the National Forest Heritage (NLN). The Strategy contains no facts and arguments justifying why the federalization of forest accounting operations can have a positive effect, especially when the experience of the last 14 years has shown extremely low efficiency of the only such institution (FSBI "Roslesinform") in terms of forest accounting operations.

On March 31, 2021, A. Kudrin, Russian statesman, stated that about 80 per cent of data sources about state's forest fund have been out of date for almost 10 years and it was necessary to update the data on almost one billion hectares, and from 2015 to 2019, only 6.5 were allocated for forest management. billion rubles. Besides, the results of forest management inspections in the Russian Federation showed an accounting disaster in forestry - the forest management system is not able to provide Russia and its citizens with real and reliable source information on the state of forest potential over the past decade and as of January 1, 2020 there is no reliable and up-to-date information about forests on area of 967 million hectares. And he also indicated that no accounting in the forest complex of Russia, contrary to the law, was not carried out.

In addition, on March 22, 2021, the State Duma of the Russian Federation began to consider a draft law improving the mechanisms of compensatory reforestation and afforestation. It proposes to increase the period for completing compensatory reforestation to three years, if during this period agrotechnical care is carried out for the created forest crops after planting, as well as persons, obliged to carry out compensatory reforestation, it will be possible to involve specialized forest institutions in the relevant activities.

It is necessary to notice that the legislator also made quite rapid metamorphoses with such documents as the Rules for reforestation and the Rules for the care of forests. The updated rules of reforestation were supplemented with a decoding of the concept of «reforestation», and to a certain extent, other points of the document were also corrected, which did not fundamentally affect the essence of the document. At the same time, A. Yaroshenko, head of the forestry department of the environmental organization Greenpeace 4811368531232249 in Russia, noted that these changes had been prepared in a hurry and noted a major omission as to the legislator in terms of regulating soil mineralization. 
From January 1, 2021, new Regulations for the care of forests came into action which have cancelled, respectively, the previous rules of 2017. According to O. Grigorieva and I. Grigoriev, the limitation of the validity of these Rules until January 1, 2027 suggests that, most likely, the drafters did not have time for a significant, all the more effective revision of the previous rules, while the new document was almost twice as much as the previous one, but references to the normative documents, in accordance with which these rules were developed, had been significantly reduced.

Before dwelling in more detail on the problem under consideration in relation to the Rostov district, it's important to notice that the official websites of the federal level, the Government of the Rostov region, the Forestry Department of the Rostov region, other websites have statistical information about the forestry sector and, in in particular, about the restoration of forests and forest belts, extremely scarce, sometimes outdated and even contradictory, and it is very difficult to clearly understand how things are with forestry in Russia and the region.

The Rostov region is located in an arid steppe forest zone and Rostov on Don is situated on the division line of Europe and Asia, forests occupy only $2.4 \%$ of the territory. The structure of forest plantations is dominated by artificial plantings (more than $70 \%$ ), including shelterbelts and anti-erosion plantations.

Southern Russia is the most vital agro-industrial center of the country. The climate in the Rostov region is becoming more and more arid. One of the key factors affecting the successful development of agriculture - a priority area of the green economy - in this territory is reclamation protective forest belts that improve the agro-industrial and environmental situation, but the intensification of negative climatic phenomena and anthropogenic activities in the Rostov region by mid-2021 led to the fact that that large part of the protective forest stands are in an extremely unsatisfactory and even deplorable state.

Protective forest breeding is the most carefull and environmentally reclamate way to prevent desertification and land degradation. Protective plantations are one of the considerable aspects in the ecological optimization of the environment; in the ecological and biological aspects, they balance the territories adjacent to them by creating a kind of microclimate. Forestry systems, including afforestation and reforestation, are widespread in drylands and aim to restore degraded land and end desertification [13].

Forest reclamation (protective afforestation) is one of the main ways to preserve and protect the land and the surrounding world. Russia can be called the homeland of steppe and protective afforestation, because in 1696 Peter I laid down an oak grove near Taganrog [14]. The history of the development of forest reclamation in our country began in the 18th century, when a decree was issued on the cultivation of protective forests in the steppes. The beginning of the 19th century was characterized by the flourishing of Russian forestry science, and forestry in Russia at the beginning of the 20th century touched emphatic success. In the first Decrees and Resolutions of the Soviet government, it was proclaimed that the fight against drought was a matter of primary importance for the agriculture of country [15].

In 1948, scientists of the country made an attempt to implement ideas on climate and nature change, wishing to prevent desertification, drought and increase land fertility, for which it was planned to create a network of forest belts with a length of more than 5,000 $\mathrm{km}$ on an area of 4 million hectares, to form an irrigation system, to build reservoirs, apply a grass-field farming system to ensure high sustainable yields in the regions located in the steppe and forest-steppe natural zones. It was assumed that the climate would be improved on an area of 120 million $\mathrm{km} 2$ and, thus, much higher yields could be obtained, the share of animal husbandry would increase and the country could be 
self-sufficient in food, as well as forest belts and irrigation, according to scientists, would radically transform flora and fauna.

Federal Research Center of Agroecology of the Russian Academy of Sciences identified the main problems of low-forest regions (Table 1).

Table 1. Problems of low-forest regions.

\begin{tabular}{|c|c|c|}
\hline Water and wind erosion & $\begin{array}{c}\text { Soil destraction and } \\
\text { degradation }\end{array}$ & $\begin{array}{c}\text { Aridization and desertification } \\
\text { of territories }\end{array}$ \\
\hline $\begin{array}{c}\text { Over the past 20 years, the } \\
\text { area of farmland exposed to } \\
\text { erosion and deflation has } \\
\text { increased by 22 million } \\
\text { hectares }\end{array}$ & $\begin{array}{c}\text { The average loss of humus is } \\
0.62 \mathrm{t} / \text { ha per year }\end{array}$ & $\begin{array}{c}\text { The forest cover of the territory } \\
\text { of the chernozem zone of } \\
\text { Russia decreased from } 35-40 \% \\
\text { to 6-15\% } \%\end{array}$ \\
\hline
\end{tabular}

Time has proven that protective afforestation can lead to tremendous results, despite the fact that such a mechanism for land improvement and stabilization of results does not require significant financial costs, is reliable and is able to maintain for a long time the lands heavily disturbed due to anthropogenic factors in good condition. Forest belts in Russia are so significantly degraded that activities for their reconstruction are on a par with socio-economic issues [16]. Today, the project, called the Stalin plan for the transformation of nature, is more relevant than ever, and many scientists believe that the forest, as well as field and forest protection belts have a positive effect on the health, productivity and productivity of soils and create a favorable climate for citizens [17-19], and are also an integral part of the program for the transition to green socioeconomic development.

2021-2030 is declared by the UN as the decade of ecosystem restoration, which means that it is necessary to activate and strengthen the large-scale restoration of degraded and damaged ecosystems, primarily forest protection zones, such actions will become effective ways to combat climate change and improve food safety, water provision and biological diversity of Russia.

Protection of the world around us and nature today is, of cause, the most urgent problem on Earth. Scientific and technological progress has stepped far forward, but the anthropogenic impact on the natural environment has intensified, which inevitably has led to an unprecedented scale of aggravation of the ecological emergency.

The problem is being made worse by the fact that there is no reliable data on the state of forests either at the federal or at the regional level. Thus, the audit of forest management in the Russian Federation shows a disastrous situation in the forestry complex - the system of procedures for forest management, which exists today, is not able to timely and reliably reflect information about the state's forest resources over the past decade. And in the Rostov region, the last inventory of forests and forest belts was carried out in 2006. Moreover, in 2019 it was recognized that desertification has already touched more than half of the territory of the Rostov region (57\%), and the landscapes of the region were oppressed.

Members of the representative public authority of the Rostov region came to the conclusion that the effectiveness of field-protective forest belts had long been proven, that forest belts in the region were urgently needed, that they significantly reduced soil erosion on the plain and created a favorable microclimate in the fields, which significantly increased productivity and recommended appropriate state bodies to eleborate a mechanism for laying new protective forest belts, which would contribute to ensuring food security. But in March 2021 it unexpectedly turned out that the planting of forest belts in the Rostov region actually reached a dead end as no funds were allocated for this event.

Despite the fact that in 2020-2021 information has appeared that the regions are trying 
to reduce the dire situation with forests and have begun the processes of their replenishment and restoration (for example, it is indicated that reforestation in Russia in 2020 was carried out on an area of more than 1.1 million hectares), nevertheless, the situation in this area continues to remain depressing, because the steppe zones are the main grain belts, in which about $80 \%$ of the grain of Russia is produced, as a result, it is necessary to use this land so that it can be as fertile as possible not only today, but also maximum harvests for future generations. Thus, protective agroforestry is the most important component of the strategy of the states of the world and Russia, which strive to preserve the natural world, rationally exploit and increase the natural resource potential, primarily for environmental and food security.

\section{Conclusion}

The study shows that the problems of change of climate, soil retrogression and desert invasion, restoration of forests and forest belts are global problems. As for Russia, it seems necessary and consequent to return to the ideas and plans of scientists at the end of the 40s of the last century about climate change in drought-affected regions of the country with oppressed soils and try to turn them into blooming fertile oases. We believe that these goals would be conductive to the measures implementation at the federal and regional levels: the adoption of a federal law on protective afforestation, the development of a strategy for the eleboration of protective afforestation in the Rostov region and the formation of agroforestry services, an inventory of the forest reclamation fund in order to obtain up-todate information on the quality and quantity of protective forest plantations with the subsequent development of appropriate measures through which it will be possible to preserve and improve the agroforestry complex. Also, an important issue is the scientific and educational support of protective afforestation and the training of highly professional qualified forest personnel.

\section{References}

1. J. Peñuelas, J. Sardans, Forests, 12(5), 603 (2021), DOI: https://doi.org/10.3390/f12050603

2. Q. Van Khuc, L. Pham, M. Tran, T. Nguyen, et al., Forests, 12(5), 521 (2021), DOI: https://doi.org/10.3390/f12050521

3. United Nations Framework Convention on Climate Change, 46, 5204 (1996)

4. Kyoto Protocol to the United Nations Framework Convention on Climate Change. Collection of Legislation of the Russian Federation, 10, 764 (2005)

5. P. P. Vasilchenko, V. V. Shevtsov, «Green economy» in the agro-industrial complex: challenges and prospects of development» (Krasnodar, 2018)

6. The SDGs Implementation Guiding Principles. JAPAN (2016), https://www.mofa.go.jp/files/000252819.pdf

7. D.-X. Li, T. Kang, Low Carbon Economy, 3, 154-159 (2012), DOI: http://dx.doi.org/10.4236/lce.2012.34020

8. A. Steblyanskaya, Foresight and STI Governance, 15(1), 74-85 (2021)

9. C. Haiye, National People's Congress: China plans 'green transformation' of economy. TOP STORIES (2021), URL; https://www.dw.com/en/npc-china-green-economy/a56774837 
10. T. H. Farooq, A. Shakoor, X. Wu, et al., Biogeosciences and Forestry, 14(2), 166-174 (2021)

11. D. Kudelas, E. Domru, A. Stoianov, D. Peters, E3S Web of Conferences, 41(2), 04023 (2018), DOI:10.1051/e3sconf/20184104023

12. E. V. Novikova, Ecolaw, 5, 3-10 (2020)

13. I. Stavi, Forests, 10(9), 737 (2019), DOI: https://doi.org/10.3390/f10090737

14. D. A. Mashtakov, A. N. Avtonomov, P. N. Proezdov, Achievements of Modern Natural Science, 6, 37-42 (2018)

15. V. Ya. Koldanov, Steppe afforestation (short essays) (Moscow, 1967)

16. M. Sergeeva, Sustainable forest management, 4 (56), 21-27 (2018)

17. A. N. Esaulko, L. V. Trubacheva, O. I. Vlasova, I. A. Volters, and V. M. Perederieva, Biosciences Biotechnology Research Asia, 13(1), 129-134, (2016)

18. K. N. Kulik, A. S. Manaenkov, A. N. Kuzenko, A. N. Salugin, In Proceedings of the Nizhnevolzhsky Agrouniversitetskiy Complex: Science and Higher Professional Education, 1(57), 23-33 (2020)

19. N. Nghia, E3S Web of Conferences, 203, 03013 (2020) 